\title{
（102）混合セメントモルタルの膨脹收縮と耐水耐虚性（第3 報）
}

\author{
永井彰一郎 - 能 味 健 次
}

普通のボルトランドセメントが其の主要水硬性化合物の珠酸三 石灰 $3 \mathrm{CaO} \cdot \mathrm{SiO}_{2}$, 珠酸二石灰 $2 \mathrm{CaO} \cdot \mathrm{SiO}_{2}$ を約 $70 \sim 75 \%$ 含有して 居て之が加水分解を受けて硬化すると珠酸石灰醷水和物 $(m \mathrm{CaO}$. $n \mathrm{SiO}_{2} \cdot x \mathrm{H}_{2} \mathrm{O}$, 主に $\mathrm{CaO} \cdot \mathrm{SiO}_{2} \cdot x \mathrm{H}_{2} \mathrm{O}$ 又は $3 \mathrm{CaO} \cdot 2 \mathrm{SiO}_{2} \cdot x \mathrm{H}_{2} \mathrm{O}$ ) を生ずる外約 20 - $25 \%$ の石灰を水酸化物として生成するるので ある。此の遊離狀の石灰の篇めにセメントモルタル, コンクリー トの耐水耐铍性に不充分な繁があるのがポルトランドセメントの 缺陷として近年專ら論議されるやうになり是を除くには多量の混 合材を用みた混合ポルトランドセメントに传るべきものであるこ とは一般の定證となつて來た。著者（永井）も既に昭和 3,4 年來 各種の混合セメントに就て試驗研究報告(「混合ポルトランドセメ ントの研究」, 第 1 8 報, 本誌, 昭和 4 6 年; 第 9 15 報, 大日本害業協會雜誌，昭和 8１0 年; 日本學汸協會報告，昭和 9 年，第 9 倦等）して來た。

更にセメントが硬化するとき其の水硬性化合物の水和熱に偖つ て著しく發熱し其の結果セメント，コンクリート施工物の中心の 蓄熱に依る高熱と其の冷却とに依つて膨脹收縮と硬化物が高熱の ため變化する等に依つて危害を及ぼすために各種の大塊コンクリ 一トには此の發熱が最も問題となつて來た。此の點に於ても多量 の混合材を均密に混用した混合セメントでは此の登等す少く從つ て低發熱性セメントとして愝堤其の他の大塊コンクリート用とし て有用なものであることは著者の所論(榎堤用セメントとしての 混合セメント」, セメント界童報, 昭和 9 10 年) である。

是等の意味から可溶性珠酸質の混合材を適當にセメントクリン カーに配合微粉碎して得られる多珪酸質混合セメントが最も優秀 な低發熱性，耐水耐龇性を持つた土木工事のコンクリート用のセ メントであることは著者の種々の報告（日本學術協會報告, 昭和 10 年, 第 10 卷, 第 3 號. 703; 大日本黨業協會雜誌, 昭和 10 , 43, 572) 及び本報第 1 2 報（本誌，昭和 $10 ， 38,431,1137$ ) 等に報告して居るし, 又外國でも各種の報告(R. W. Carlson and G. E. Troxell, A. S. T. M. Proc., 1933, 33, (2), 484; R. E. Davis, R. W. Carlson, J. W. Kelly and G. E. Troxel!, Amer. Concr. Inst. .Jonrn., (Proceeding, 30), 1934, 5, (4), 369) に依つ ても確定的に此の多珠酸質混合セメントの優秀なことを證明して 居る。著者は年來主唱して試驗研究を重ねて居る是等の多珪酸質 混合セメントの優㑧性を證明するために禁土セメント，高級及び 普通ポルトランドセメント, 高曥セメント等を比較試料に供して 多珪酸型混合セメントに就ての其の後の試瞼研究の一部を䋥めて 始に報告しや5。

\section{（1）セメント及び混合材䚾料}

本報の多珠酸筫白士を混合した各種混合セメントの試驗研究に 比較のため他の種のセメントをも同時に試料に供した。其の種類 は攀土セメント 1 種, 高級ポルトランドセメント 1 種, 普通ポ ルトランドセメント 1 種, 高爈セメント 1 種の都合 4 種を用 みた。
决に多珠酸質混合セメントとしては普通のポルトランドセメン ト用のクリンカーに多珪酸質白土を多量に混合し微粉に粉碎して 得られるるのである。先づ此のために使用した多速酸䝷白土は著 者が此の數年來種々の白土を各地から集めて比較研究して居るす のの詳細は既に別報混合ポルトランドセメントの研究其の他で報 告して居るから省略するが其の代表的のわのの主要化學成分を头 の第 1 表に示さ5。之に依つて見る と全珃酸分は別府座可溶白

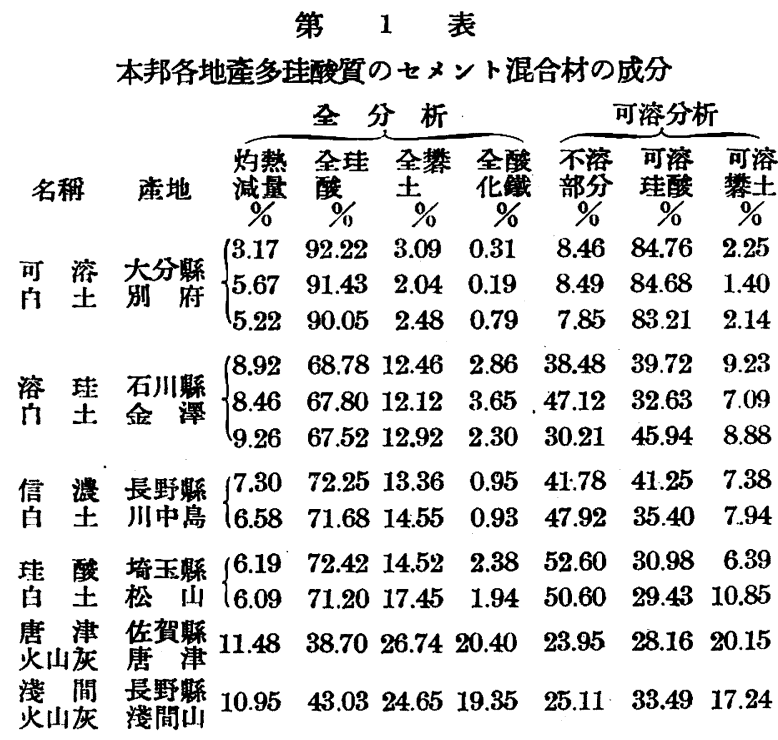

土が最も多く他の 攀土以下は極く少量である。之に對し 信濃白 土, 珪酸白土, 溶珪白土の順に全球酸は $72 \%$ 位から $68 \%$ 位の 間に下り反對に攀土分が 12〜13\% から 15〜17\% 位に埥加し， 酸化鐵も 2〜3\% に垷して來る。セメント混合用としては此の中 で全珠酸, 可溶珠酸共に最も多い九州别府附近座の可溶白土が最 も優良で, 全攀土, 可溶攀土が次第に㙩加する溶珪白土, 信濃白 土、珪酸白土などが之に次ぎ，唐津火山灰，淺間火山灰，伊豆火 山灰などは可溶攀土が可溶酸化鐵と共に著しく增加し反對に可溶 珪酸が著しく減少して來るから決して優良な混合材とは云ふこと が出來ない。從つて始には示さなかつたが既に著者が各種の䆩驗 をして報告した伊太利火山灰（大日本窑業協會雜誌，昭和 9, 42, 20，261）は日本の各種火山灰とよく類似して居るすのであるから 伊太利で盛んに製造使用されて居る火山灰ポルトランドセメント は決して優良な混合セメントとは云へないであらら。次に獨逻で 多く製造使用されて居るトラスなる混合材は日本の上述の珠酸白 土值とよく類似して居ることは著者が親しく獨逸トラスを取り奇

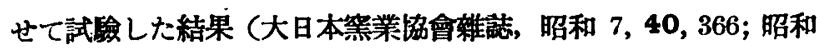
8, 41, 565) で明かで之でも佔可溶珪酸が少く, 可溶攀土が多い 嫌がある。從つて獨逸でよく製造されるトラスポルトランドセメ ントよりる本邦座で妶に報告するやらに可溶性珪酸が $85 \%$, 全球 酸が $90 \%$ 以上もある様な可溶白土が最も優良な混合材で之を用 みて製造した可溶白士混合セメントのシリカセメント，金剛セメ 


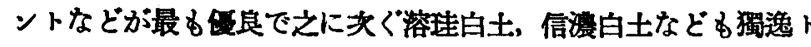
ラスよりる優良好適な混合材である。

夯に此の可溶性球酸の多い各種の白土の中可溶白土の最も良い

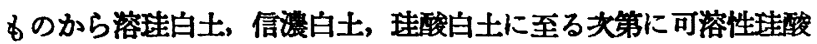
の少いあのに至る迄の略中庸の平均と慨められる溶球白土を用る

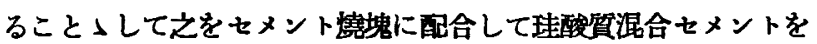
調製した。此の際白土の混合を $40 \%$ の樣に多くするときは混合
セメントが凝結硬化が非常に遲くなるのが常であるから之に少量 の石灰を湿合すると此の凝結硬化が充分早められることを認めた 著者の他の研究報告（永井及び松岡叞馬「混合ポルトランドセメ ントの研究」，第 13 報一多量の石灰混合セメントの試揄，大日

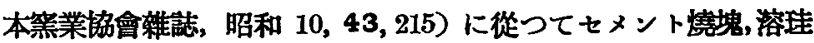
白土, 消石灰の 3 種の混合セメントをも試製した。夯の第 2 表

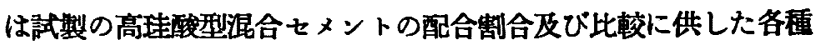

\section{第 2 表 市眨又は試製のセメント試料の物理性}

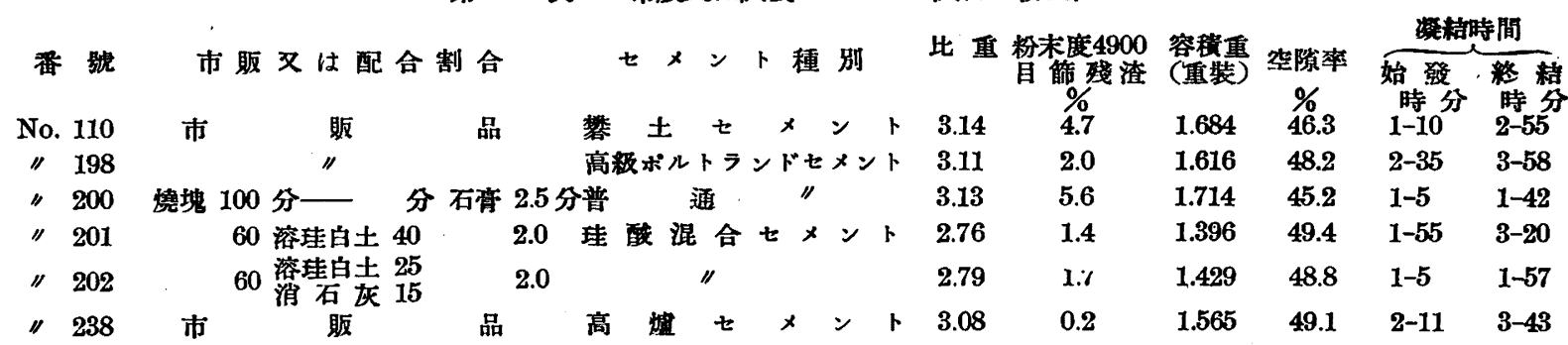

の市販セメント試料の各種物理性を比較したものである。此の結 果で見て特に顯著な差異は珪酸混合セメントが非常に小さい比重 (2.76〜2.79) でポルトランドセメントの夫れ (3.11〜3.13) の約 10 $\%$ む小いこと, No. 202 は消石灰の混和に侤つて No. 201 よ り凝樎時間が初まつて No. 200 のポルトランドセメントと同等に なつて來て居ることである。

夯の第 3 表は是等 6 種のセメントの化學成分の比較表である が始に最も㙷著な差異は No. 201, No. 202 の高珪酸型混合ポル トランドセメントは妁熱娍量が 4.3〜 4.9\% の樣に多いことは普通
セメントならば風化が甚げしくて凝結が荤く, 硬化强度が非常に 低下する位の量であること，不溶解牫楂が $23 \sim 31 \%$ の樣に多量 なことは特に他に類例がないこと，全珪酸 33〜38\% の樣に多い こと, 全石灰が 40 45\% の樣に少いことなどは何れもセメント クリンカーが少く溶珪白土の混合が多いことに起因して居る。佾 No. 202 には遊離石灰が $5 \%$ 近くもあることは消石灰を加へたこ とから來て居ることである。尚此の No. 201，No. 202 共に攀土 が 8〜9\% 前後の様に多いのは溶珪白土を用みて居ることから來

\section{第 3 表 市販及び試製のセメント試料の化學成分}

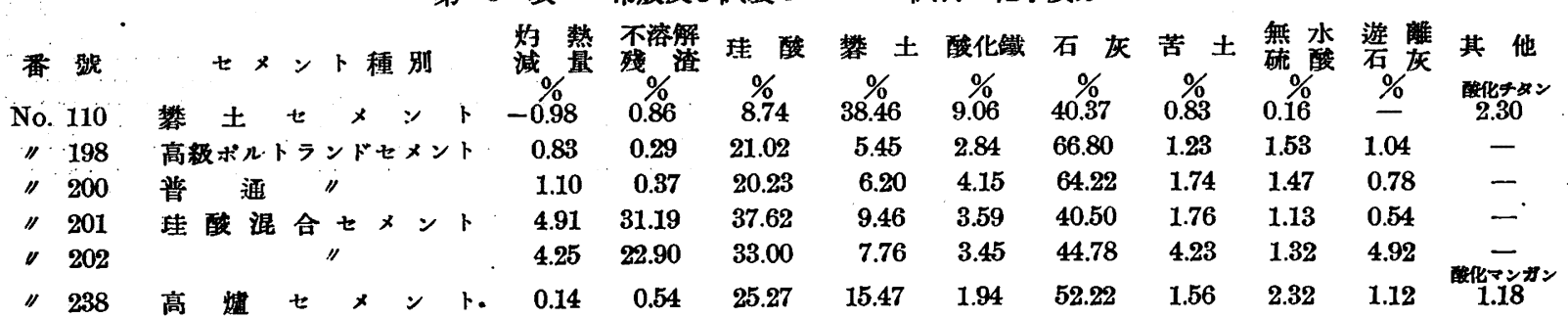

て居ることで秩父セメントの迋酸セメントが攀土が $8 \%$ 前後ある のとよく似て之は攀土 $15 \%$ 前後の混合材を使用することから來 て居ることで大阪墨業のシリカセメント, 豐國セメントの金㓮セ メントなどの栐に禁土の少い九州別府の可溶白土を用みた混合セ メントと異る點である。他の攀土セメント，高峬セメントが夫ネ 獨特の化學成分, 各種物理性を示すことは高級及び普通ボルトラ ンドセメントの夫等と共に本報研究に各種のセメント試料を用み て比較研究を行つた主旨に添ふるのであることは云ら迄もない。

\section{（2）硬絊及び軟䊾モルタルの强度}

上揭各種のセメント試料の比較試驗のため先づ其のモルタルの 硬化强度を比較して本報試憸に供試する試料としての適否を見 た。其の霨めに次の 2 様に行つた。

(A) 現行規格の 1:3-硬練モルタルの 酎壓及び抗張强度試驗 一般のセメント試驗に行はれる日本標準規格の JES 28 及び JES 29 に制定してあるポルトランドセメント及び高爐セメントの規 格硬練（水セメント比 26〜34\%) の 1:3-モルタルで敨打成形し

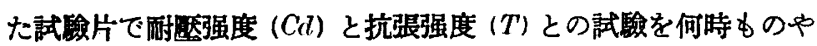

らに行つた。

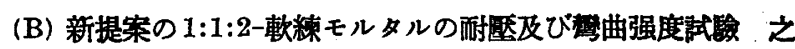
は著者等が數年來上記の規格硬練モルタルの强度試驗法が不合理 不自然至極なるのである點を指摘して水セメント比を 60 70\% にし何等能打などの外仕事を與へないで流込成形に依る硬化强度 を試驗する方沠として瑞西及び獨逸法の長を探つて數年來試羷研 究をして居る方法で其の詳細は別報（永井:「セメントの軟練モル

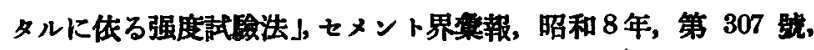
第 309 號; 昭和 9 年, 第 312 號, 第 313 號, 第 320 號; 昭和 11 年, 第 335; 日本學術協會報告, 昭和 9 年, 9, 第 1 號; 昭和 10 年, 10, 第 3 號) に詳しいから省略し本報第 1 報以來探用し て居ると同樣に此の軟練 1:1:2-モルタルの耐邀强度 $(C w)$ 及び出 曲强度 $(B)$ とを比較試匳した。

以上 (A) 及び (B) の 2 方法で上揭 6 種のセメント試料の比 較試驗結果を次の第 4 表に表示して比較した。此の結果で見られ ることは第 1 報に於て得たと同じやらに(A)硬練規格 1:3-モルタ ルの强度試卧では球酸混合セメントの 2 種;高蜢セメント等の混 合セメントは普通ポルトランドセメント, 高㿮ポルトランドセメ 
第 4 表 市販及び試製セメント試料のモルタルの强度

(A) 規格硬練 1:3-モルタルの强度

\begin{tabular}{|c|c|c|c|c|c|c|c|c|c|c|c|c|c|}
\hline \multirow[b]{2}{*}{ 番 號 } & \multirow[b]{2}{*}{$\begin{array}{l}\text { 水セメ } \\
\text { ント此 }\end{array}$} & \multicolumn{5}{|c|}{$C d:$ 耐原强度 $\left(\mathrm{kg} / \mathrm{cm}^{2}\right)$} & & \multicolumn{5}{|c|}{$T:$ 抗張强度 $\left(\mathrm{kg} / \mathrm{cm}^{2}\right)$} & \multirow{2}{*}{ 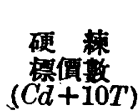 } \\
\hline & & 3 日 & 7 日 & 28 日 & 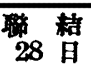 & $\begin{array}{l}\text { 合 } \\
(C d)\end{array}$ & $\begin{array}{l}\text { 水セx } \\
\text { ント比 }\end{array}$ & 3 日 & 7 日 & 28日 & 慗 & $\begin{array}{l}\text { 合 柿 } \\
(T)^{-1}\end{array}$ & \\
\hline No. 110 & $28 \%$ & 559 & 551 & 569 & 699 & 2378 & $26 \%$ & 42.4 & 38.9 & 38.5 & 50.0 & 170.1 & 4079 \\
\hline " 198 & 30 & 445 & 581. & 675 & 640 & 2341 & 28 & 43.5 & 49.4 & 53.5 & 62.4 & 208.8 & 4429 \\
\hline$\checkmark 200$ & 29.6 & 440 & 512 & 520 & 575 & 2045 & 27.6 & 41.6 & 41.4 & 44.8 & 50.4 & 178.5 & 3830 \\
\hline " 201 & 32 & 352 & 506 & 640 & 676 & 2174 & 30 & 34.6 & 41.8 & 56.2 & 55.9 & 188.5 & 4059 \\
\hline " 202 & 30.8 & 398 & 542 & 627 & 641 & 2216 & 28.8 & 29.8 & 39.2 & 51.7 & 52.4 & 173.1 & 3947 \\
\hline " 238 & 30 & 462 & 546 & 592 & 755 & 2355 & 28 & 45.5 & 51.4 & 51.8 & 55.7 & 204.4 & 4399 \\
\hline
\end{tabular}

(B) 軟練 1:1:2-モルタルの强度

\begin{tabular}{|c|c|c|c|c|c|c|}
\hline \multirow[b]{2}{*}{ 番 } & \multirow[b]{2}{*}{ 皽 } & \multicolumn{5}{|c|}{ 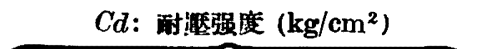 } \\
\hline & & 3 日 & 7 日 & 28 日 & $\begin{array}{c}\text { 筑 } \\
28 \text { 稍 }\end{array}$ & $\begin{array}{l}\text { 合 }(C w) \\
\text { 計 }\end{array}$ \\
\hline No & 110 & 564 & 570 & 462 & 671 & 2267 \\
\hline " & 198 & 289 & 428 & 518 & 572 & 1807 \\
\hline " & 200 & 222 & 335 & 417 & 440 & 1417 \\
\hline " & 201 & 98 & 146 & 312 & 321 & 877 \\
\hline " & 202 & 112 & 175 & 324 & 336 & 947 \\
\hline " & 238 & 210 & 322 & 509 & 493 & 1534 \\
\hline
\end{tabular}

\begin{tabular}{|c|c|c|c|c|c|c|}
\hline \multirow{2}{*}{$\begin{array}{l}\text { 水七メ } \\
\text { ント比\% }\end{array}$} & \multicolumn{5}{|c|}{$B$ : 粼曲强度 $\left(\mathrm{kg} / \mathrm{cm}^{2}\right)$} & \multirow{2}{*}{ 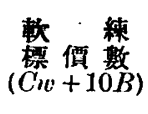 } \\
\hline & 3 日 & & 28 日 & 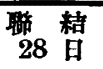 & $\begin{array}{c}\text { 合 計 } \\
(B)\end{array}$ & \\
\hline 58.8 & 78.0 & 73.7 & 69.3 & 87.0 & 308.0 & 5347 \\
\hline 60 & 57.9 & 69.6 & 71.8 & 77.8 & 277.1 & 4578 \\
\hline 55.5 & 49.0 & 54.8 & 61.3 & 68.7 & 233.8 & 3752 \\
\hline 61 & 27.2 & 38.9 & 62.7 & 66.0 & 194.8 & 2825 \\
\hline 60 & 32.6 & 41.4 & 56.7 & 68.4 & 199.1 & 2938 \\
\hline 58 & 41.1 & 55.0 & 69.0 & 84.8 & 249.9 & 4033 \\
\hline
\end{tabular}

ントには短期 3 日の强度は少るが 7 日で既に之を迫ひ越し更に 28 日では充分之を帘いで標價数に於ても之を完全に洨いで居る ことだけで見ると混合セメントは他の種のセメントに優るとも劣 ら以樣に見えるが,之は規格硬楝モルタル泆の最大の缺陷で 26〜 $32 \%$ 等の水セメント比では禁土セメント，高級及び普通ポルトラ ンドセメントの完全な加水分解加其の水硬性化合物の加水分解式 から見て非常に不足で不充分な硬化を强制して居るのに對し，混 合セメントでは其の約 $60 \%$ を占めるクリンカー部分の加水分解 には此の 26 32\% の水で充分で完全な硬化をさせるからである。 之に對して (B) 新提案の㜞練モルタル法では水セメント比を小型 フローテーブルで其の可塑性を試驗して定めるので大體 55〜65 \%の㴍に多くなるからセメントの水硬性化合物の加水分解には管 ろ充分過ぎて殊に混合セメントの樣にクリンカー部分が $60 \%$ の ものには著しく過多になるので强度は短期 3 日, 7 日は普通セx

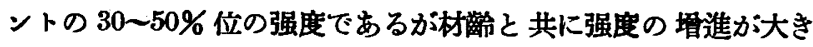
いから28 日にもなると著しく增大して其の後 3 筒月, 6 個月， 1 個年すすれば普通セメントを夋いで來ることは既に多くの試剑報 告(上揭)で明确にされて居る。妶に(A)硬練モルタル法が不合理 で(B) 僌紼モルタル法が合理的なことを示最す顯著な例はNo.

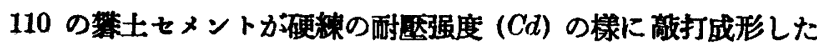

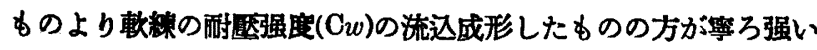
强度を與へて居る事で明白で之は硬練法か棓打成形にも拘らず水 セメント比が小さく水硬性化合物が完全な加水分解と硬化をして 居ないためである。上述の栐に軟料洗では水量を 1 種の可塑性試 䮲のフローテーブルのフローを同一にして決定したので混合セメ ントの様に混合材 $40 \%$ を占めるものには常に多くて 65 70\%の 水をメント比になり而もクリンカー部分 $60 \%$ に對しては過大で あるために水が非常に過剩になつて上揭の様に强度が婜際以上弱 く出たり头節の膨脹收綰試驗にも多くは收縮勝ちになるのは此の

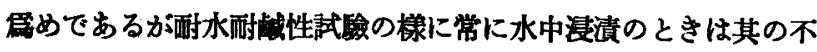
利なく空中硬化に於てのみ一見不利の椂に見える結果となるので 此の默は目下水セメント比を $45 \%$ に減少したものも行つて居る から後日報告与る機會があらら。

\section{（3）モルタル試驗片に依る路脹收樎 と耐水耐醽性試驗}

上揭第 4 表の (B) 㜞練 1:1:2-モルタルの梁形 $(4 \times 4 \times 16 \mathrm{~cm})$ 試 驗片と同一方法で多數の試驗片を成形し其の兩端に近く（端から 約 $1 \mathrm{~cm})$ 白金のビンを差し込んで硬化させ其の白金ビンの頭の面 に微細な十字楾を引小、て此の左右 2 個の十字の間陭を第 1 報第 2 圖（本誌，昭和 $10,38,435$ ) に示した膨脹收縮測定器に体つ て正確に湘定することにした。其の一般の方法,操作等は第 1 報,

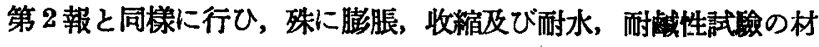
熯は 4 週以後 4 週每に之を測定し 32 週迄に達し, 最後に耐

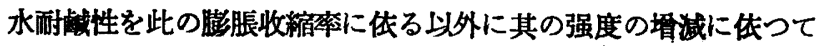
試驗比較することにして慜曲强度を試驗し更に耐麼强度を試驗し て上揭第 4 表の水中 4 週强度々試驗し或は同一材额(32 週間) 水 中浸漬の試驗片の强度と比較試驗した結果などを头の第 5 表に表 示しやう。向此の試驗では各種䮵類溶液としては第 1 及び第2 報 の結果に体つて最も侵蝕作用の激しい碝酸通の代表として $10 \%$ $\mathrm{Na}_{2} \mathrm{SO}_{4}$ 溶液を用み, 餘り作用は激しくないが海水の主成分とし て $10 \% \mathrm{NaCl}$ 溶液げけを用るることにした。最初成形 1 日後の 長さを基楚にし 4 涸間水中硬化をなした後是等の溶液に浸漬し て 4 週のbのを $8(4+4)$ 週材龄， 28 週浸漬のものを $32(4+28)$

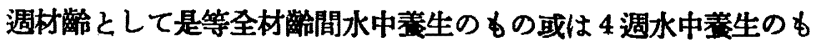
のと其の强度を比較し, 長さの膨脹收樎 $(\mathrm{mm} / 10 \mathrm{~m})$ は何れる成 形 1 日後水中漫漬前のわのの長さを基淮にしたことは前諸報に 於けると全く同様にした。從つて 4 週水中硬化だけでは理酸混合 セメントや高淔セメントなどの湿合セメントは不充分であるため

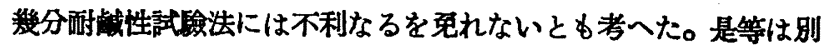
報を以て 4 週水中硬化後更に 4 週水中硬化を重ねると少抄し 溫して硬化を促進して充分混合セメントの硬化をも促進して各種

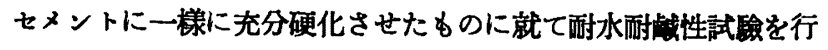
つたものなどを報告し、目下其の方法に传つて行つて居るから是 等は後日第 4 報以下に報告しやう。

此の結果から見ると次の樣な種々の笘が明かに認められ批制が 


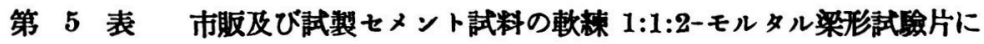

传る膨脹, 收縮 と耐水酎性試驗

\begin{tabular}{|c|c|c|c|c|c|c|c|c|c|c|}
\hline \multirow{2}{*}{ 番 } & \multirow[b]{2}{*}{ 號 } & \multirow{2}{*}{$\begin{array}{l}\text { 浔清用水及 } \\
\text { は溶 液 別 }\end{array}$} & \multicolumn{2}{|c|}{$\begin{array}{c}\text { 浐張 }(+), \text { 收樎 }(-), \\
\mathrm{mm} / 10 \mathrm{~m}\end{array}$} & \multicolumn{6}{|c|}{ 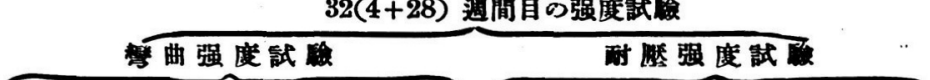 } \\
\hline & & & $\begin{array}{l}8(4+4) \\
\text { 遇 }\end{array}$ & 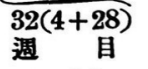 & $\mathrm{kg} / \mathrm{cm}^{2}$ & $\begin{array}{l}\text { 水中弲度K } \\
\text { 對ちる指数 }\end{array}$ & $\begin{array}{l}4 \text { 蔨水中弲度 } \\
\text { に對する指数 }\end{array}$ & 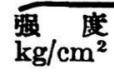 & $\begin{array}{l}\text { 水中品度 } \mathrm{K} \\
\text { 数子指数 }\end{array}$ & 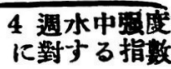 \\
\hline \multirow{3}{*}{ No. } & & & -0.7 & +2.9 & 58.9 & 100 & 85 & 288 & 100 & 60 \\
\hline & 110 & $10 \% \mathrm{Na}_{2} \mathrm{SO}_{4}$ & -0.2 & -2.9 & 35.6 & 60 & 51 & 213 & 74 & $\cdot 44$ \\
\hline & & $10 \% \mathrm{NaCl}$ & 0 & -2.9 & 49.0 & 83 & 71 & 325 & 113 & 67 \\
\hline \multirow{3}{*}{$"$} & & & $\mathbf{0}$ & +1.4 & 78.8 & 100 & 110 & 457 & 100 & 88 \\
\hline & 198\{ & $10 \% \mathrm{Na}_{2} \mathrm{SO}_{4}$ & +50.0 & \multicolumn{2}{|c|}{ (8 调間目以後鎪裂, } & \multicolumn{4}{|c|}{ 崩埣著しくなり長さ，强度ひ測定不可能となる) } & \\
\hline & & $10 \% \mathrm{NaCl}$ & +6.0 & +1.4 & 77.3 & 98 & 108 & 486 & 107 & 94 \\
\hline \multirow{3}{*}{ " } & \multirow{3}{*}{200} & & -1.4 & 0 & 59.0 & 100 & 96 & 427 & 100 & 102 \\
\hline & & $10 \% \mathrm{Na}_{2} \mathrm{SO}_{4}$ & +16.0 & \multicolumn{6}{|c|}{ 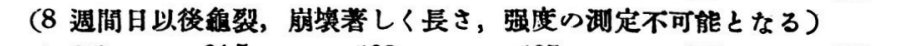 } & \\
\hline & & $10 \% \mathrm{NaCl}$ & -1.4 & +2.1 & 64.5 & 109 & 105 & 427 & 100 & 102 \\
\hline \multirow{3}{*}{ " } & \multirow{3}{*}{201} & 水 & -4.3 & +1.4 & 85.8 & 100 & 137 & 572 & 100 & 183 \\
\hline & & $10 \% \mathrm{Na}_{2} \mathrm{SO}_{4}$ & -2.1 & -3.6 & 109.1 & 127 & 174 & 497 & 87 & 159 \\
\hline & & $10 \% \mathrm{NaCl}$ & +1.4 & +4.3 & 100.0 & 117 & 160 & 487 & 85 & 156 \\
\hline \multirow{3}{*}{ " } & \multirow{3}{*}{202} & 水 & +5.0 & +2.9 & 80.2 & 100 & 144 & 526 & 100 & 162 \\
\hline & & $10 \% \mathrm{Na}_{2} \mathrm{SO}_{4}$ & -0.7 & +2.1 & 109.4 & 136 & 193 & 556 & 106 & 172 \\
\hline & & $10 \% \mathrm{NaCl}$ & -2.9 & +1.4 & 100.2 & 125 & 177 & 485 & 92 & 150 \\
\hline \multirow{3}{*}{ " } & \multirow{3}{*}{238} & 水 & +5.6 & +6.4 & 83.4 & 100 & 121 & 555 & 100 & 109 \\
\hline & & $1 \% \mathrm{Na}_{2} \mathrm{SO}_{4}$ & +0.7 & +2.9 & 93.2 & 112 & 135 & 375 & 67 & 74 \\
\hline & & $1 \% \mathrm{NaCl}$ & +1.4 & -1.4 & 111.4 & 134 & 161 & 503 & 92 & 99 \\
\hline
\end{tabular}

出來る。(a) 普通及び高級ポルトランドセメントの様にポルトラ ンドセメント采のセメントは $10 \% \mathrm{Na}_{2} \mathrm{SO}_{4}$ の様な硫酸噞液で最 も著しく侵されて最初から膨脹が激しく逐には裂裂し, 崩壞して しまふことは炏の第 1 圖ででも明かである。然し $10 \% \mathrm{NaCl} の$ 様な盟化物では殆んど何等の著しい作用が認められない。(b) 禁 土セメントの樣に䄯土酸石灰が主要成分のセメントは單に水中に

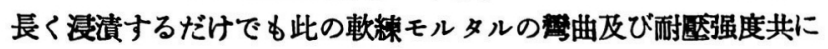
減少するのは硬化生成物の攀土酸石灰衤水和物, $7 \mathrm{CaO} \cdot m \mathrm{Al}_{2} \mathrm{O}_{3}$ ・ $n \mathrm{H}_{2} \mathrm{O}$ (郎ち $2 \mathrm{CaO} \cdot \mathrm{Al}_{2} \mathrm{O}_{3} \cdot n \mathrm{H}_{2} \mathrm{O}$ 又は $3 \mathrm{CaO} \cdot \mathrm{Al}_{2} \mathrm{O}_{3} \cdot n \mathrm{H}_{2} \mathrm{O}$ ) が

\section{第 1 圆各種セメント試料 軟練 1:1:2-モルタル 粱形試驗片下依了水, $10 \% \mathrm{Na}_{2} \mathrm{SO}_{4}, 10 \%$ $\mathrm{NaCl}$ 溶液中浸清に依了的裂崩壤狀㮩}

110: 松土セメント

202: 珪酸混合セメント

198: 高䄲ポルトランドセメント 201：珪酸混合セメント

200: 普通ボルトランドセメント 238: 高䡒セメント

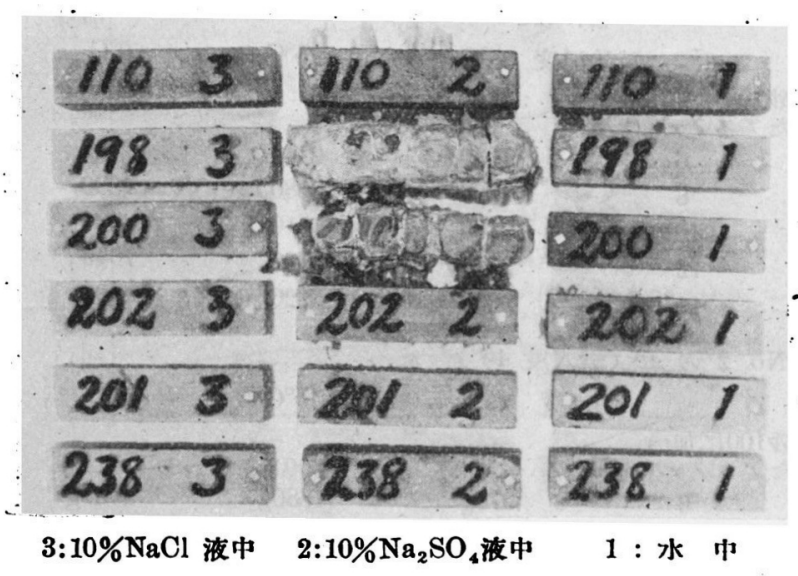

水に溶け易いからである。10\% $\mathrm{Na}_{2} \mathrm{SO}_{4}$ !溶液中では特に著しく强 度が低下し $10 \% \mathrm{NaCl}$ 溶液中では之より稍影䭚が少いが夫れで す水中よりは低下が多い。(c) 珄酸混合セメントは水中 4 週强度

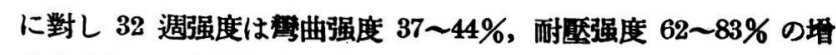
大を來し，10\% $\mathrm{Na}_{2} \mathrm{SO}_{4}$ 及び $10 \% \mathrm{NaCl}$ 溶液中の强度の剒大は 水中よりす著しいことは最す注目すべきことで之はやはり前述し た樣に其の中のクリンカー部分から遊砠する石灰分が全部混和材 中の可溶性珪酸と結合して趎酸石灰監水和物 $l \mathrm{CaO} \cdot m \mathrm{SiO}_{2} \cdot n \mathrm{H}_{2} \mathrm{O}$ (郎ち $3 \mathrm{CaO} \cdot 2 \mathrm{SiO}_{2} \cdot n \mathrm{H}_{2} \mathrm{O}$ 又は $\mathrm{CaO} \cdot \mathrm{SiO}_{2} \cdot n \mathrm{H}_{2} \mathrm{O}$ ) を生じて水 に不溶になるのみでなくやはり硬化力を持つて居るから斯く長期 に强度の堵進があり、ポルトランドセメントの時の樣に遊雄石灰 に基づく膨脹, 乘裂, 崩壤などがない。之が混合セメントの最も重 大な長所である。(d) 高烣セメントも混合セメントとして上述珪 酸混合セメントに夾いで混合セメントとしての長所ああるが混合 材に珪酸䄪 30〜33\% の外箘土が約 $13 \sim 15 \%$ 位含まれて居るか ら可溶性珠较ばかりから成つて居る球酸混合セメントよりは此の 耐水耐战性が劣つて居る。(e)混合セメントに於てす $10 \% \mathrm{Na}_{2} \mathrm{SO}_{4}$ 溶液に依る侵され方が多く $10 \% \mathrm{NaGl}$ 溶液の方が少いのはやは り硫酸根に依つて $3 \mathrm{CaO}^{\circ} \mathrm{Al}_{2} \mathrm{O}_{\mathbf{2}} \cdot 3 \mathrm{CaSO}_{4} \cdot n \mathrm{H}_{2} \mathrm{O}$ などの生成に依 るすのであることが知れる。(f) 混合セメントの方が 8 週, 32 週 の水中及び塹類液浸漬共に其の試驗片に何等の異常を認めないで 强度も最も大きいことは耐水耐战性は混合セメントがポルトラン ドセメント，禁土セメントに㟨り，特に理酸混合セメントが最も 優良なことを最も明確に示して居る。

\section{(4)}

\section{픈}

本報は 第 1 及び第 2 報に引き續き混合セメント特に珪酸質 混合セメントの耐水耐战性に就て比較研究を重ねたもので其の妍 旨を摘錄すとる,

（1）多球酸貿の天然產混合物として珪酸白土(埼王䅫)，溶球白 士(不川牃), 可溶白土(大分夥), 信莨白土(長野慗)の 4 種の十数 個試料の全分析, 可溶分析を行ひ可溶珃酸のみ最も多い可溶白土 (大分睬)最す優れ，他の 3 種は大同少異であることを認めた。

(2) 是等 4 種の白土中溶珪白土を用ひ 2 種の 球酸混合セメン 
トを試製し，之と同一クリンカーから試製した普通ポルトランド セメント，其の外市販の高級ポルトランドセメント，攀土セメン ト, 高曥セメントの各 1 種, 合計 6 種のセメント試料の比重, 凝結時間，粉末度，1:3一硬練モルタルの耐笑及び抗張强度; 1:1：

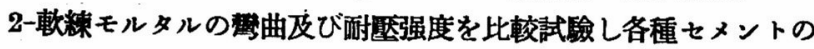
特徽, 偍劣及び現行硬練:モルタル試驗法の不合理を指摘して論 したた。

(3) 各種セメント試料の $1: 1: 2$-㜞練モルタル, 梁形試醶片で

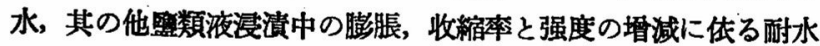
耐战性とを比較检討して何れの點から見ても违酸混合セメントが 最も傢良な結果が得られることを確め，ポルトランドセメント系 のセメントに共通の最大缺敌郎ち加水分解，硬化したものの中に
多量に牫る水酸化石灰に传るすのであることを强く指摘し殊に垠 堤, 橋脚，防波殹などのコンクリート用セメントには此の珠酸混 合セメントの最適性に就て論じた。

佾此の種の研究，更に各種セメントペーストの凝結硬化中の發 熱の問題からあ混合セメント殊に珠酸混合セメントが低發性の檤 一であることは既報（本誌，昭和 10,38, 1595) の通りであるが 此の整に就ても目下一層詳細に研究中であるから後日更に報告し や5。

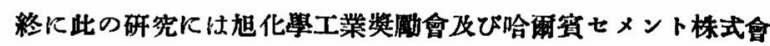
社からの載助を受けたものであるてとを妓に明記して謹んで感謝 の意を表したい。

（日本建筑籷工株式會社）（昭和 11 年 2 月 10 日受理）

\section{(103 104) ストレート・アスファルトの研究（第3 4 報）}

市川良正

\section{（第3 赫） 蒸氣精製アスファルトのカの測定}

著者は第 1 報及第 2 報に於て蒸氣精製アスファルトに就て特 に蒸氣の量を多く使用して丁稆に製造した試料及び蒸氣の量を減 らして粗暴に製造した試料を拔取り，各試料に就て其一般性狀， 成分，分子容及び炭素及水素を定量し之を報告したが，更に本報 に於ては兩試料の力を測定し之を比較した。

力の测定に於てはシートアアスファルト及びワーレナイト・ビチュ リシックの細粗混合物に最も多く使用される針入度郎ち $41 \sim 50$, 86〜100 に就て行ふことを目的とし, 試料 No. 1 より No. 1 の

$$
\text { 第 } 1 \text { ．．圆 }
$$

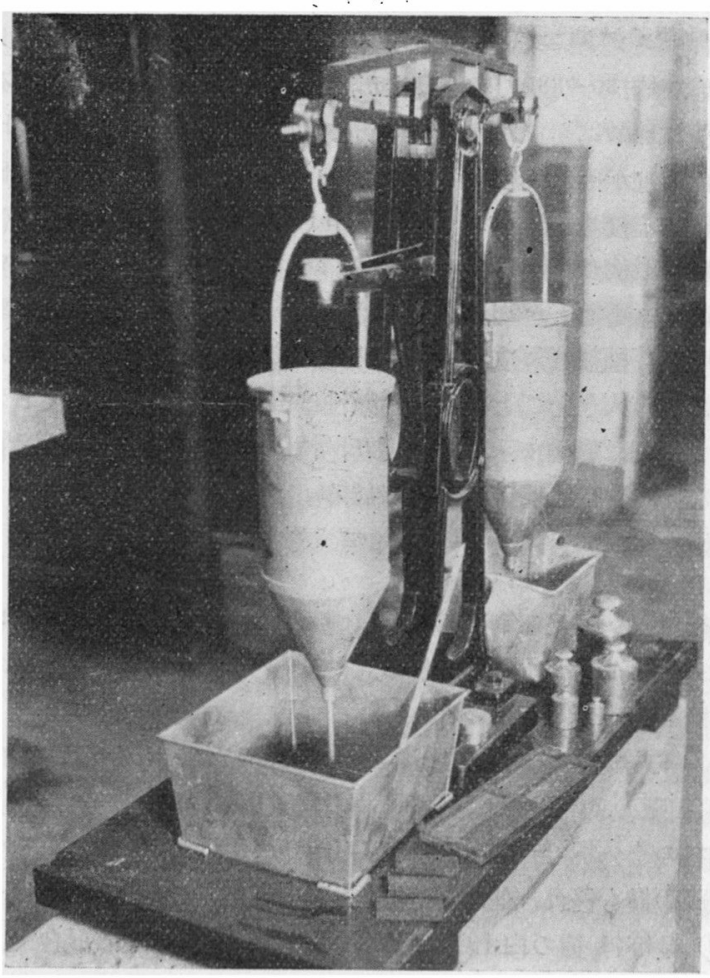

47 及び No. 1 の 88 の 2 種を, 又試料 No. 2 よりは No. 2 の 45 及 No. 2 の 89 の 2 種を選定し, 其閦着力, 抗張力及び 衝慗抵抗力を比較測定した。

\section{1. 璆萧力試験 (Cementing strength)}

膠着力測定には第 1 圖の如きシュッテ氏 (Schutte) の腤着力試 䛗器を使用したものであつて，篎ろ Bending strength と稱する 方が適當かも知れない。

郎ち標準砂 (20 目節を通過し 30 目笠に止まる䞨砂) 々試料 スファルトとを適當な割合に配合した加熱混合物を幅 $2.5 \mathrm{~cm}$ ，長さ $11 \mathrm{~cm}$, 厚さ $0.6 \mathrm{~cm}$ の長方形に造り上げて試驗片となし, 之を試 驗器にかけ, $0^{\circ}, 15^{\circ}, 25^{\circ} \mathrm{C}$ の各溫度に於て徐々に荷重を加一試 驗片が 2 つに折れた時の荷重を以て膠着力を表はした。

而して以下に擧げた數字は 8 個の試驗片の平均值である。 試 驗 成 績

(a) 針入度 $41 \sim 50^{c}$ の場合の比較

No. 1 の 47 (針入度 $47^{\circ}$ )

\begin{tabular}{|c|c|c|c|}
\hline 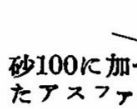 & $25^{\circ} \mathrm{C}$ & $15^{\circ} \mathrm{C}$ & $0^{\circ} \mathrm{C}$ \\
\hline 6 & $1030 \mathrm{~g}$ & $2140 \mathrm{~g}$ & $2990 \mathrm{~g}$ \\
\hline 8 & 2200 & 3680 & 4830 \\
\hline 10 & 2160 & 4510 & 6080 \\
\hline 12 & 2110 & 4830 & 7040 \\
\hline 14 & 2080 & 5220 & 8300 \\
\hline
\end{tabular}

No. 2 の 45 (針入度 $45^{\circ}$ )

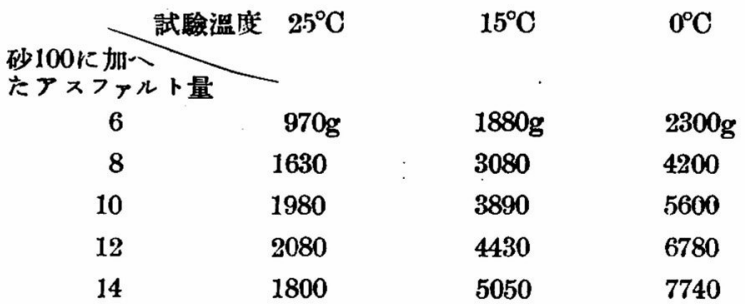

(b) 針入度 $86 \sim 100^{\circ}$ の場合の比較 